\title{
SUFISM IN THE POEMS OF AHMAD KAMAL ABDULLAH
}

\section{(Sufisme dalam Sajak Ahmad Kamal Abdullah)}

Badrul Munir Chair

badrul_munir_chair@walisongo.ac.id

Faculty of Ushuluddin and Humanities

Walisongo State Islamic University (UIN Walisongo), Semarang-Indonesia

To cite this article (Rujukan artikel ini): Badrul Munir Chair. (2021). Sufism in the poems of Ahmad Kamal Abdullah. Malay Literature, 34(1), 89-102. http://doi.org. 10.37052/ml34(1)no5

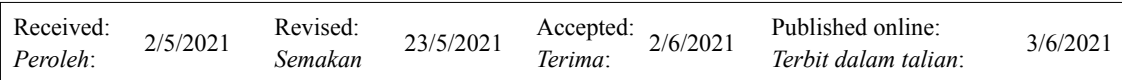

\begin{abstract}
This study aims to find sufi values in the poems of Ahmad Kamal Abdullah (Kemala), a modern Malaysian poet. In this study, the writer uses sufi literary theory to analyse poems by Kemala. The poems are taken from three collections of Kemala's poems, namely Ziarah Tanah Kudup (2006), Syurga ke Sembilan (2009), and Dhikr Serenades; Titir Zikir (2010). This study of sufi elements is the poems of Kemala employs the theory of Seyyed Hossein Nasr and concerns three major elements of tasawwuf (sufi mysticism), that is, the Divine, Mankind and spiritual wellbeing. The conclusion that can be drawn from this study is that the poems of Kemala are inseparable from sufism. The Divine is, in Kemala's poems, an aim in mankind's life journey. The Divine in this case is personified as light or "Nur". Mankind, in Kemala's poems, is depicted as the Salik or traveller in search of an end to his journey, which is the Divine Himself. While spiritual wellbeing is about the search and contemplation of human life.
\end{abstract}

Keywords: Ahmad Kamal Abdullah, sufism, poem, sufi, tasawwuf 


\begin{abstract}
Abstrak
Penelitian ini bertujuan untuk mengetahui kandungan nilai-nilai sufisme dalam sajak-sajak Ahmad Khamal Abdullah (Kemala), penyair Malaysia modern. Dalam penelitian ini, penulis melakukan identifikasi terhadap puisi-puisi Kemala menggunakan teori-teori sastra sufistik. Puisi-puisi tersebut adalah daripada tiga buku kumpulan puisi Kemala iaitu Ziarah Tanah Kudup (2006), Syurga ke Sembilan (2009), dan Dhikr Serenades; Titir Zikir (2010). Penelitian terhadap nilai-nilai sufisme dalam puisipuisi Kemala menggunakan teori Sayyed Hossein Nasr tentang tiga unsur utama kajian tasawuf, iaitu kudrat Tuhan, kudrat manusia, dan kebajikan rohani. Daripada penelitian ini didapati bahawa puisi-puisi Kemala sangat dekat dengan unsur sufisme. Kudrat Tuhan dalam puisi-puisi Kemala diposisikan sebagai tujuan pencarian daripada perjalanan hidup manusia. Tuhan dalam hal ini dipersonifikasikan sebagai "Cahaya" atau "Nur". Kudrat manusia, dalam sajak-sajak Kemala diposisikan sebagai seorang Salik, iaitu pengembara yang terus mencari tujuan akhir perjalanannya, iaitu Tuhan itu sendiri. Sedangkan kebajikan rohani berisi sekitar pencarian dan perenungan akan hakikat kehidupan manusia.
\end{abstract}

Kata kunci: Ahmad Kamal Abdullah, sufisme, sajak, sufi, tasawuf

\title{
INTRODUCTION
}

Sufi elements entered Malay culture at least in the $13^{\text {th }}$ Century CE through sufi orders, educational institutions and literature, and subsequently into the culture of the peoples of the Malay archipelago. Evidence of the early influence of sufi thought can be seen from inscriptons of the mausoleums of the kings of Pasai and Melaka (Malacca), as well as on other Muslim tombstones from the $13^{\text {th }}$ to the $15^{\text {th }}$ Century CE. However, the most important period in the literature of the Malay Archipelago began at the turn of the $16^{\text {th }}$ and the $17^{\text {th }}$ century, when the islamization of the inhabitants of the Archipelago was carried out by sufi mystics, who spread Islam through texts interpreted and written in Malay (Hadi, 2004: 17).

The classical Malay texts produced at the end of the $16^{\text {th }}$ to the $19^{\text {th }}$ Century $\mathrm{CE}$ are numerous and of all kinds and forms. Among these is a manuscript that tells the life history of the Prophet Muhammad s.a.w., major figures in Islam and the like. Works of that period are dominated by those influenced by Islam with a strong sufi tradition. The majority of the works produced at the beginning of the rise of Islam are written with a strong sufi influence. 
The tradition of sufism in the Archipelago had a big influence on Malay ports of the period; the most well-known among these is Sheikh Hamzah Fansuri, who succeeded in bringing Malay literature to a higher level. Hamzah Fansuri's works have had a lasting influence and have inspired legions of writers after him (Hadi, 2001: 3-4).

The sufi-influence poems of Hamzah Fansuri not only inspired the Malay poets of Indonesia but also poets from Malaysia, all of whom have the same Malay roots. One modern Malaysian poet influenced by Hamzah Fansuri is Ahmad Kamal Abdullah.

This study will discuss the sufi values in the poems of Ahmad Kamal Abdullah (known as Kemala). To this researcher, the poems of Kemala have an interesting aspect. On the one hand, Kemala is very much influenced by the sufi poems of previous poets, such as Hafez al-Shirazi, Fariduddin Attar, Jalaluddin al-Rumi, Iqbal, and Malay poets such as Amir Hamzah and Hamzah Fansuri. However, on the other hand, there is a new intertextuality and a new quest for modernity in the various types and forms of Kemala's poems without abandoning sufi elements. This study was carried out through library research using a qualitative method.

\section{LITERATURE REVIEW}

\section{The Meaning of Sufism}

Etymologically, sufism cannot be separated from tasawwuf. The term tasawwuf itself comes from the root word "sufi". The first to use the term "sufi" was an ascetic by the name of Abu Hasyim al-Kufi (d. 150H), in Iraq. The term "sufi" means "pure". A sufi is thus someone who is pure, and sufis are those who have purified themselves through all kinds of means, both physically and spiritually (Harun Nasution, 1990: 56).

In another version, the term "sufi" comes from suf, which denotes the wool that was used in the garments of the sufis from Syria (Arjun, 2003, p. 104). There is also another opinion, no less popular, that the term originates from Suffah, which was the name of a place near the mosque in Madinah (Medina), where the Prophet Muhammad s.a.w. used to teach his companions, among them Abu Dzar and others (Abubakar Aceh in Wachid, 2008: 38).

As a specialized term then, sufism or tasawwuf means cleansing oneself (takhali) from being ignoble, and beautifying oneself with goodness in order to be closer to Allah or to reach a higher maqam (station) (Ibrahim, 2004: 3). Sheikh Ahmad Zarruq (d. ca. 1494 CE) has stated the basis of sufism 
is tawhidic knowledge (knowledge of the Oneness of God), from whence a seeker is able to experience the delicacy of tawakkal (trust in God) and peace of the soul. If he does not, he will not have a "healing of the heart" ("penyembuhan hati", in Fadhalla Haeri, 2000: 4).

According to Chittick (2001: 14) sufi teachings consist of three dimensions: shariah (exoteric path), thariqah (esoteric path), and haqiqah (mystical truth). When one has trodden down the sufi path and entered the state of thariqah, one will experience a spiritual transformation that leads to the perfection of the soul.

\section{RELATIONSHIP BETWEEN SUFISM AND LITERATURE}

Tasawwuf was the most important factor for the spread of Islam in Southeast Asia (Alwi Shihab, 2009: 46). The majority of historians and researchers agree that the spead of Islam in Southeast Asia took place on a spectacular scale because of the role and contributions of important sufi figures. This, according to Alwi, was because the sufis were more compromising and compassionate, and did not show any bias in terms of differences in ethnicity, race, language or geographical location.

In their mission to spread Islam in Southeast Asia, the sufis carried out community service, and provided contributions and aid in the spirit of togetherness and real brotherhood. They also modified local customs and traditions to fall in line with Islamic teachings. Through wisdom and a positive approach, they were able to spread the word of God, as the Prophet s.a.w. had done (Alwi Shihab, 2009: 47). The sufis also understood that the Archipelago's populace had a liking for the arts, and therefore poetry and art became a medium for the proselytization of Islam.

Dissemination of sufi literature in the Malay Archipelago was pioneered by Hamzah Fansuri (d. ca. $1527 \mathrm{CE}$ ), and his efforts were carried on by his student, Sheikh Syamsudin (Shamsuddin) Sumatrani. Hamzah Fansuri had a profound influence on the later development of Malay literature. If tasawwuf played an important role in the spread of Islam in this region, then surely Hamzah Fansuri is an important figure in the history of the region's thought and religion.

Using literature as a medium for the spread of sufism, such as was done by Hamzah Fansuri, was not new. Before him, Ibn 'Arabi and Jalaluddin Rumi had also used the language of literature as a medium to spread Islam heavily infused with sufi values. 
Sufi works, according to Braginsky (1994: 3), were compositions about the perfection of the soul, with a unique characteristic, and whose aim was mushahadah, that is, witnessing the Oneness of Allah. The unique characteristic was that they were not concerned with the beauty of form to present their aims indirectly, because what was intended was for readers to achieve enlightenment and bring them to mushahadah.

The sufis chose to use symbolic expression, such as metaphors, innuendos, similes and linguistic symbols to depict emotions, their existence, and their longing. Therefore, they were also known as ahlul isharah (companions of the symbol). Symbols were used, according to Muhammad Zaki Ibrahim (2004: 15), because there were no exact words or known expressions that could be used to express the sufis' thought and emotions. For this reason, the use of signs and symbols became a pressing need for the sufis, with the assumption that these could bring senses and emotions closer together and give them a visualizable form, expressible then as words.

\section{THREE MAIN ELEMENTS OF SUFISM FROM THE STUDIES OF SEYYED HOSSEIN NASR'S}

Seyyed Hossein Nasr (in Hadi, 2004: 14), states that on the surface, tasawwuf or sufism concerns three elements: the Divine, Mankind and spiritual wellbeing. The final aim is the Divine, the beginning of the journey is Mankind in his lowly condition, and it is suluk (journeying) and a sufi order that will connect humankind with God. The analysis of the sufi content of Kemala's poems is performed using Seyyed Hossein Nasr's theory of the three major elements of sufism.

For Nasr, tasawwuf is the heart of Islamic Revelation. It provides an energy to all aspects of life, whether social or intellectual but especially spiritual. For human beings to possess an awareness of the Divine, they must train, sharpen and strengthen this awareness by implementing sufi teachings till there is a balance in the between what is in the brain and in the heart. Also, to achieve the sufi spiritual elevation, one must go through it in stages or stations (maqamat), beginning with taubah (repentance), zuhud (asceticism), wara' (piety), sabar (forebearance), tawakkal (trust in God) and so forth (Nasr, 2020: 90-95).

The spiritual journey meant by Nasr is love, because only love can connect the soul of the seeker with what is sought, which is spiritual in nature. Only by means of sufism is it possible to have a realization of the 
Divine, to which the names and characteristics of God are directed, that is, through achieving ahsan taqwim (the best condition) (Hadi, 2004: 171).

The identification of the sufi elements in Kemala's poems is done through employing Seyyed Sayyed Hossein Nasr's theory, namely the three main elements of tasawwuf.

\section{ABRIEF BIOGRAPHY OF AHMAD KAMALABDULLAH (KEMALA)}

Ahmad Kamal Abdullah, better known as Kemala, was born on 30 January 1941 in Gombak, a district in Selangor bordering Kuala Lumpur. His mother's name was Rukiah Amir and his father's was Abdullah Hj. Daud. Kemala received his early education in several schools in Kuala Lumpur. In 1956, Kemala was a student at Institut Dharma. His highest attainment in education is the Doctor of Philosophy (Malay Literature), which he obtained from Universiti Kebangsaan Malaysia in 2000.

Kemala is a prolific poet. Not confined to writing poetry, Kemala has also written short stories, essays, and drama scripts. From early on, Kemala has also published dozens of single poems, among them Timbang Terima (1970), Meditasi (1972), Era (1975), Kaktus-Kaktus (1976), 'Ayn (1983, 1989), Pelabuhan Putih (1989), Titir Zikir (1995), Mim (1999), Ziarah Tanah Kudup (2006), Syurga ke Sembilan (2009), and Sumsum Bulan Rawan (2011). Kemala's works, especially his poems, have been translated into various foreign languages including Chinese, Urdu, French, German, Dutch, Slovenian, Spanish and Serbo-Croatian.

In 2011, Kemala was awarded the $11^{\text {th }}$ Anugerah Sastera Negara (National Literature Award), which earned him the title of National Literature Laureate. The National Literature Laureate Award is given by the government of Malaysia to writers writing in Malay who have made excellent contributions to developments in the field of literature through their creative works, thought and through high-quality literary activities (see Tan Sri Muhyiddin Yassin, 2011: 1-3).

\section{SUFI VALUES IN THE POEMS OF AHMAD KAMAL ABDULLAH}

The enthusiasm of Malay poets for Islamic-inspired literature is proven by the countless Malay poems that convey a philosophy that al-Ghazali calls the "soul of Islam", that is, sufism. According to Ahmad Kamal Abdullah (2009: 3), Malay poets and writers took on themes tackled by the great sufis themselves, such as tazkiyyah an-nafs (purification of the self), tawakkal (trust in God), mahabbah (spiritual love), and ridha (contentment). 


\section{The Divine in the Poems of Kemala}

The Divine is one of the central themes in Kemala's poems. In presenting his ideas on the Divine, Kemala often uses symbols. These symbols are couched in his diction and metaphors, and are necessary to represent something that otherwise is unattainable. The use of such figures of speech is for the expression of meanings that the poet wishes to convey, which defies ordinary words or speech for representation of his thoughts and feelings.

The types of symbolism used by Kemala in his poems provides them with a unique sufi nuance. He often uses celestial elements as metaphors, such as "bulan" [the moon], "langit" [the sky], "nur" [light], and "cahaya"[light]. Apart from this, Kemala uses metaphors from the natural world such as "langit" [the sky] to present his idea of God as something "Yang Tak Terjangkau" [unattainable].

The dominant word choice for Kemala to "represent" the Divine in his poem is that of "Cahaya" or "Nur" [light]. Kemala presents this "Cahaya" or "Nur" as something that is out of reach and transcendent. His depiction of the transcendent appearance of "Nur" can be seen in his poem "Ghazal Syawal Nurul Fatehah untuk Aisyah Insyirah" ["A Shawal Ghazal from Nurul Fatehah to Aisyah Insyirah"] which is as follows:

\section{Awaslah terhadap kemilau kaca, itu hanya kilauan palsu Yang kita tunggu hanya sesorot Nur-Nya menghidup kalbu Tataplah bulan sabit selepas subuh yang syahdu Dekap rindu Rabiah mengilau menawan nafsu...}

[Beware the sheen of glass, it is a false sheen

What we await is only the beam of His Nur that enlivens the heart Look at the crescent moon after the serene dawn The longing embrace of Rabiah shimmers, overcoming lust...]

In this excerpt, Kemala emphasizes that the sheen of glass that we often see is a false one, because the true sheen is that of the beam of His "Nur", the Divine light. It is this Divine light that truly enlivens the heart.

Kemala's concept of "Nur" in this poem reinforces the explanation of Ibn 'Arabi that the existence of the world is like a thing seen from a distance, without a soul, as if in a blurry mirror (Muhyiddin Ibn Arabi in Anshori: 87). For the sufis, "cahaya" [light] in many cases is a favourite spiritual term and 
is often made one of the symbols for the essence of the Divine. This is in refernce to the Qur'an, Surah an-Nur verse 35 which means:

"Allah is the Light of the heavens and the earth. The example of His light is like a niche within which is a lamp; the lamp is within glass, the glass as if it were a pearly [white] star lit from [the oil of] a blessed olive tree, neither of the east nor of the west, whose oil would almost glow even if untouched by fire. Light upon light. Allah guides to His light whom $\mathrm{He}$ wills. And Allah presents examples for the people, and Allah is Knowing of all things."

In sufi literature, the Divine is often represented using all kinds of symbols. Kemala often uses all kinds of metaphors to refer to God, the most common being "Nur", "Cahaya", and "Langit", which are, we may add, transcendent as well as immanent. Immanent here means that these metaphors can be perceived by the senses or with the naked eye, however, when given more thought, they are something - as metaphors - that is transcendent and out of human reach. On the one hand, "Nur", "Cahaya", and "Langit" can be observed or seen, on the other they are out of reach.

Apart from "Nur", "Cahaya", and "Langit", the metaphor of "Laut" [the ocean] is also used to represent the Divine, as can be seen in the following:

Bulan, bulan violet putih jatuh kasih pada karang dan laut bulan, bulan violet sahih pendaran sukma direnggut maut (Violet, Abdullah, 2006: 78)

[Moon, violet white moon admiring coral and ocean moon, true violet moon the luminscence of the soul is snatched away by death]

The metaphor of the sea is often used by sufis to refer to the Divine or the Most Expansive, while corals represent strength. In the above poem, Kemala, through the image of "bulan violet" [the violet moon], expresses his "jatuh kasih" (admiration) to the corals and the ocean. "Bulan violet" and "laut", as used in this poem, are two images that usually occur far apart, so that the admiration of the subject is a secret one, left till the "pendaran sukma" [luminescence of the soul] is "direnggut maut" [snatched away by Death]. 
The spiritual journey of Kemala in this expansive ocean is actually a journey from the physical world towards the spiritual world, or the spiritual journey of the sufis towards the realm of truth. Kemala often uses expressions that describe delving into a endless ocean, or, as Kemala puts it, a journey to "laut yang tak berpantai" [an ocean withour shores].

\section{Mankind in the Poems of Kemala}

Kemala's poems specifically depict human beings as travellers, wayfarers or Salik, who capture spiritual experiences — expressed or implied — along their journey. Kemala's consciousness of his position as an ordinary (human) Salik can be seen in the following poems:

aku perindu kamil yang 'ngembara

mikraj di langit arasy-Mu

(Tasbih, Ahmad Kamal, 2010: 95)

[I am the desirer of perfection who trav'ls

the stair on the sky of your throne]

jejak-jejak musyafir mencari diri

makna yang kupungut

pada pertemuan pertama

rindu tumbuh

dalam berpisah.

(Bulan Putih, Ahmad Kamal, 2006: 94)

[the traces of wayfarers looking for themselves

a meaning I gathered

at the first meeting

longing grows

in separation.]

Adakah bulan rawan

Dipeluk zikir salik perindu

Adakah nestapa lautan

Bertemu penawar mujarab

Yang Satu.

(60 Nestapa, Ahmad Kamal, 2006: 48) 
[Is a vulnerable moon

Embraced by the remembrance of a longing traveller

Has a sea of misery

Met its true cure

The One.]

The representation of the self as a Salik is found in the majority of Kemala's poems, and constitutes his effort to present his "perjalanan batin" [spiritual journey] within the frame of his "hakikat diri" [true self], until he finds "Yang Satu" [the One]. Kemala positions himself as "perindu kamil yang "ngembara" - a wayfaring desirer-whose journey will not end until he has "Bertemu penawar mujarab" [found the true cure], which is "Yang Satu" [the One].

Fritz Meier (2004: ix) states that mystics who are on a quest to find the Divine existence call themselves wayfarers (Salik) because mysticism in Islam is a long journey or migration from the physical world to the spiritual one.

The image of the Salik in Kemala's poems is often represented by the metaphor of the "burung" [bird]. This bird metaphor presntes the traveller as one who flies through the universe in the form of an inner journey. The symbol of the bird can be found in the following poem:

Burung-burung Kudus

melayah ke kota kekasih

mengukuh diri.

Kicau burung-burung Kudus

tasbihnya birahi diri.

Layahan burung-burung Kudus

kicau rawan

mencari kekasih yang hilang.

(Burung-Burung Kudus, Ahmad Kamal, 2006: 36)

[Holy birds

Swoop down to the city of lovers

To strenghten themselves.

The chirping of the holy birds

Is a hearty praise. 
The swooping birds

chirp forlorn

looking for the lover lost.]

Based on a variety of interpretations of classical sufi works, we know that the use of the bird metaphor is noften linked to the spiritual world. The bird in this case is a symbol for the human soul on its transcendental journey, its theological quest, or the spiritual ascension of a mystic to achieve holy union with his Creator (Md. Salleh, 1992: 10).

Most famously, in sufi literature the bird metaphor was used in the work Mantiq at-Tayr, an allegorical poem by Farid ad-Din 'Attar (618/1221). In this poem, a group of birds wishing for a judgement from their king, the Simurgh, go on a quest to have an audience with him. All 30 of them face exhaustion on their journey, and finally at the end of their journey they realize that the Simurgh is none other than they themselves (see Meier, 2004: 97).

\section{Spiritual Wellbeing in Kemala's Poems}

Kemala's poems are also filled with reflections on values in living that lean towards spiritual aspects. Kemala writes much about the journey, religious experience, and expresses his feelings about matters he discovers in his life.

Kemala's poems often express his religious experience on his "quest" and this can be seen in the poems "Titir Zikir", "Syurga ke Sembilan" and "Ziarah Tanah Kudup" which are poems written when he visited several places, such as Los Angeles, California, Brastagi, Danau Toba, London, Zurich, an others. Although he went to foreign places, he continuously reflects on questions of life which lead to substantial matters that are often questions central to sufis. His reflections and quest can be seen in the following poem:

\footnotetext{
"Adakah umur menjadi jawapan untuk sebuah kebahagiaan?" dan "Adakah hubb menjadi payungmu?" "Adakah maut akan menyirnakan keindahan batini?" (Bulan Kesumba, Ahmad Kamal, 2006: 96)

["Is age and answer for a happiness?" and "Is $h u b b$ your shield?" "Will death obliterate spiritual beauty?"]
} 
di mana pun insan asalnya satu

terpencar, cemar atau mulia

(Di Kota London, Ahmad Kamal, 2010: 127)

[wherever man is, his origin is one scattered, polluted or noble]

Lapangkan dadamu dengan hujah jujur

"Beda butir dan fikir mujur, hikmahnya berjalur.

Seni bestari alam rohani menghablur.

Ulama-hukama hargai luhur.

Pewaris Nabi-nabi bak bintang di langit bertabur!"

(Surat Wasiat, Ahmad Kamal, 2006: 73)

[Relieve your heart with honest argument

"Different points and good thoughts, the line of wisdom.

The art of the wise spiritual realm crystallizes.

Scholars value truth.

The heirs of the Prophet are like stars in the sky strewn!']

These poems are questions about the nature and meaning of life, and contain messages of liberation and enlightenment of the soul. Questions about the meaning of life often arise in the poems of Kemala. He is a poet who is restless, always looking for answers for questions that continuously bother him in life. Questions such as "Adakah umur menjadi jawapan untuk sebuah kebahagiaan?" [Is age an answer for a happiness] and "Adakah maut akan menyirnakan keindahan batini?" [Will death obliterate spiritual beauty] are philosophical questions about the meaning of life and also show the awareness that this life is not eternal. Although Kemala oftentimes finds answers for his questions, in his restlessness, at times he does not. Therefore, he must always continue on his journey in life.

Kemala's poems are almost completely dominated by poems that have as their central theme a contemplation of the universe in its entirety, whether from the angle of the realities of human life or their relationship with God. Although there is a wide spectrum of themes in Kemala's poems, they almost always focus on the contemplation of something that he has encountered in his human journey. 


\section{CONCLUSION}

Kemala continues the sufi tradition in Malay literature begun by Hamzah Fansuri, who introduced both thematic and formal innovation and thus was reponsible for modernizing Malay literature. Kemala's poems come from his contemplations and deep spiritual experiences. The expressions included in his poems show the poet's clarity of heart, to the extent that his poems are full of sufi elements that are rich in teachings about sufism and religion, such as are found in the Qur'an.

The influence of sufism in Kemala's poems can be determined from the sufi elements of the Divine, Mankind and spiritual wellbeing. The Divine in Kemala's poems is positioned as an aim for the human quest in life's journey. The Divine, in this case, is represented as "Cahaya" or "Nur". Mankind, in Kemala's poems, is a Salik, a traveller and seeker on a quest to find the ultimate aim for his journey, which is God Himself. Spiritual wellbeing concerns the quest and the contemplation about the nature of human life.

In the majority of his poems, Kemala represents himself as the Salik-a traveller on the path of sufism - on a long spiritual journey to find the essence of his self.

A large number of Kemala's poems are the poet's reflections and remembrances to bring himself closer to God. Kemala often does such remembrances, which are like a meditation to him, and a contemplation of the experiences that he has gained on his journey as a Salik. Such meditation and contemplation do not only involve himself but are also in harmony with the universe to gain inner peace.

The natural world as a landscape in Kemala's life has a position that is no less important in the quest to find the meaning of life and the Divine. Social life is a reflection of the wisdom and experience that the Salik gains. In his social life, Kemala expresses his contemplations, full of sufi content.

\section{REFERENCES}

Ahmad Kamal Abdullah. (1988). Unsur-unsur Islam dalam puisi Melayu modern.

Dewan Bahasa dan Pustaka.

Ahmad Kamal Abdullah. (2006). Ziarah tanah kudup. Dewan Bahasa dan Pustaka. Ahmad Kamal Abdullah. (2009). Syurga ke sembilan. Insandi, 2009.

Ahmad Kamal Abdullah. (2010). Dhikr serenades: Titir Zikir. Institut Terjemahan

Negara Malaysia.

Arjun, Syaikh Muhammad Shadiq. (2003). Sufisme: Sebuah refleksi kritis. Pustaka Hidayah. 
Braginsky, V. (1994). Nada-nada Islam dalam sastera Melayu klasik. Dewan Bahasa dan Pustaka.

Braginsky, V. (2007). Bersahut-sahutan sepanjang zaman: Perpaduan manusia dan laut dalam puisi Hamzah Fansuri, Kemala, dan Latiff Mohidin, article presented at Prosiding Seminar Kesusasteraan Bandingan Antarbangsa, 2007.

Chittick, William C. (2001). Jalan cinta sang sufi, ajaran-ajaran spiritual Jalaluddin Rumi. Qalam.

Hadi, Abdul W.M. (2001). Tasawuf yang tertindas, kajian hermeneutik terhadap karya-karya Hamzah Fansuri. Paramadina.

Hadi, Abdul W.M. (2004). Hermeneutika, estetika, dan religiusitas. Mahatari.

Haeri, Syaikh Fadhalla. (2000). Jenjang-jenjang sufisme. Pustaka Pelajar.

Md. Salleh Yaapar. (1992). Ziarah ke Timur: Ta'wil sebagai bentuk hermeneutika Islam, in Ulumul Qur'an, Vol. III No. 3, 1992.

Meier, F. (2004). Sufisme merambah ke dunia mistik Islam. Pustaka Pelajar.

Muhammad Zaki Ibrahim. (2004). Tasawuf hitam putih. Tiga Serangkai.

Muhyiddin Yassin. (2011). Agung Anugerah Sastera Negara ke-11 Kepada YBhg. Dato' Dr. Ahmad Kamal Abdullah. Lecture read at the Anugerah Sasterawan Negara award ceremony, May 2011.

Nasution, Harun. (1990). Filsafat dan mistisisme dalam Islam. Bulan Bintang.

Saheeh International. (1997). The Qur'an (Arabic text with corresponding English meaning). Saheeh International.

Schimmel, Annemarie. (1986). Dimensi mistik dalam Islam. Pustaka Firdaus.

Shihab, Alwi. (2009). Akar tasawuf di Indonesia. Pustaka Iman.

Wachid B.S., Abdul. (2008). Gandrung cinta, tafsir terhadap puisi Sufi A. Mustofa Bisri. Pustaka Pelajar. 